\title{
UPAYA MENINGKATKAN HASIL BELAJAR ILMU PENGETAHUAN ALAM (IPA) DENGAN METODE PEMBELAJARAN TWO STAY TWO STRAY (TSTS)
}

\author{
SYAEFUL BACHRI \\ syaefulbachriii@gmail.com \\ DASMO \\ amo0903unindra@gmail.com
}

Program Studi Pendidikan Fisika, Fakultas Teknik, Matematika \& Ilmu Pengetahuan Alam Universitas Indraprasta PGRI

\begin{abstract}
The purpose of this research is to improve result of studying science using two stay two stray (TSTS) learning method by controlling the students' ability in the beginning. This research used experimental method with ANAKOVA analysis. The sample used is the students of class VIII SMP Negeri 242 Jakarta with 60 students' divided into control and experimental class with each totaling 30 samples. The results of this research are: First, controlling influence the students' ability in the beginning, there is difference result of studying science which is significant between the students who study by using two stay two stray and using conventional method $\left(F_{\text {hitung }}=15,05>F_{\text {tabel }}=4,01\right)$. Second, controlling influence the students' ability in the beginning, the result of study science, the students who study by using stay two stray is better than using conventional model $\left(t_{\text {hitung }}=3,892>t_{\text {tabel }}=1,672\right)$.
\end{abstract}

Keywords: Two Stay Two Stray, Result of Study, Science

\section{PENDAHULUAN}

Pendidikan IPA diharapkan dapat menjadi wahana bagi peserta didik untuk mempelajari diri sendiri dan alam sekitar, serta prospek pengembangan lebih lanjut dalam menerapkannya di dalam kehidupan sehari-hari. Pembelajaran IPA bertujuan membantu agar siswa memahami konsep IPA dan keterkaitannya dengan kehidupan sehari-hari (Rediarta dkk, 2014:2). Pentingnya mata pelajaran IPA berbanding terbalik dengan minat belajar peserta didik terhadap mata pelajaran tersebut. Sampai saat ini masih banyak peserta didik yang memandang IPA sebagai salah satu mata pelajaran yang sulit. Hal ini menjadikan salah satu penyebab hasil belajar IPA yang masih tergolong rendah. Berdasarkan dokumen ujian tengah semester yang peneliti peroleh di SMPN 242 Jakarta diperoleh hasil seperti pada tabel 1. Dari tabel tersebut dapat dianalisis bahwa hasil belajar peserta didik pada pelajaran IPA bervariasi jika dilihat dari nilai kriteria ketuntasan minimalnya (nilai $\mathrm{KKM}=70,00$ ). Pada tahun 2015, dari 4 kelas terdapat 2 kelas yang nilai rata-rata IPAnya berada di atas KKM. Sementara pada tahun 2016 dan 2017 terdapat penurunan dimana pada tahun 2016 dari 4 kelas hanya 1 kelas yang rataratanya di atas KKM dan 2017 tidak ada yang rata-rata kelasnya di atas KKM.

Tabel 1. Rata-rata Nilai Ujian Tengah Semester

\begin{tabular}{ccccc}
\hline \multirow{2}{*}{ TAHUN } & \multicolumn{4}{c}{ Mata Pelajaran IPA } \\
\cline { 2 - 5 } & VIII A & VIII B & VIII C & VIII D \\
\hline 2015 & 70,5 & 65,5 & 55,6 & 72,5 \\
2016 & 50,67 & 72,6 & 65,7 & 60.5 \\
2017 & 41,4 & 53,2 & 60,7 & 54,5 \\
\hline
\end{tabular}

Sumber: Daftar Nilai pegangan guru kelas VIII SMPN 242 Jakarta 
Hasil belajar IPA dipengaruhi oleh banyak faktor. Salah satu faktor penting yang mempengaruhinya adalah cara penyampaian materi IPA yang dilakukan guru dalam hal ini model pembelajaran. Suprijono (2006:45-46) menyatakan bahwa, "model pembelajaran dapat diartikan sebagai landasan praktik pembelajaran hasil penurunan teori psikologi pendidikan dan teori belajar yang dirancang berdasarkan analisis terhadap implementasi kurikulum dan implementasinya pada tingkat operasional di kelas". Dalam proses belajar mengajar, penggunaan model pembelajaran yang tepat akan berpengaruh terhadap ketercapaian pemahaman peserta didik.

Pada dasarnya semua model pembelajaran yang pernah diterapkan selama ini mempunyai kelebihan dan kekurangan. Guru harus terus mencoba model pembelajaran yang lebih efektif dan efisien sehingga menghasilkan kompetensi hasil belajar peserta didik sesuai dengan harapan. Leonard, Hasbullah, \& Nurani (2016) menuliskan teachers must do their best effort as the learning process could be done effectively and efficiently, particularly to build students' motivation and spirit. Guru tidak bisa lagi mengandalkan model pembelajaran informatif. Model pembelajaran informatif adalah model pembelajaran dimana guru lebih banyak menggunakan ceramah di hadapan peserta didik. Sementara peserta didik hanya mendengarkan dan mencatat. Model pembelajaran ini tergolong konvensional, karena peserta didik hanya akan membayangkan sesuatu yang abstrak.

Mengingat betapa pentingnya model pembelajaran dalam proses belajar mengajar berbagai disiplin ilmu termasuk IPA di sekolah, maka penggunaan model pembelajaran yang baik dan sesuai dengan materi yang diajarkan adalah mutlak harus dikuasai oleh guru. Banyak model mengajar yang dapat digunakan oleh guru dalam pelaksanaan proses belajar mengajar. Dimana model pembelajaran tersebut mengharuskan peserta didik aktif dalam proses pembelajaran. Salah satu model pembelajaran yang tepat untuk digunakan adalah pembelajaran Two Stay Two Stray (TSTS).

Menurut Lie (2006:61), "metode pembelajaran Two Stay Two Stray (dua tinggal dua tamu) merupakan suatu metode pembelajaran dimana peserta didik belajar memecahkan masalah bersama anggota kelompoknya, kemudian dua orang dari kelompok tersebut bertukar informasi ke dua anggota lain yang tinggal". Sementara Maonde dkk (2015:145) mengatakan bahwa, "TSTS was developed by Spencer Kagan (1992) and used cooperatively with number head together. This method is commonly used for all subjects and students' level. This method enables the students to share information to the other groups. The procedure of TSTS is (a) students work together in a group of four, (b) after finished, two member from each group stray to two other groups, (c) two member stayed have job to share their work and information to those who come to their group, (d) the two strayed members get back to their own group and report what they have found, and (e) the groups match and discuss their work."

Model pembelajaran ini dapat digunakan untuk semua mata pelajaran dan untuk tingkat usia anak didik. Model pembelajaran ini mengharapkan keaktifan dan partisipasi peserta didik yang memberikan penekanan pada penggunaan struktur tertentu yang dirancang untuk mempengaruhi pola kreatif peserta didik, dan memberikan waktu kepada peserta didik untuk berpikir dan merespon serta saling membantu antara satu dengan yang lain dalam menyelesaikan permasalahan tertentu. Model pembelajaran ini dapat meningkatkan penguasaan akademik peserta didik. Selain itu, dengan model pembelajaran ini peserta didik tidak akan cepat merasa bosan dalam belajar IPA. Dengan TSTS diharapkan akan terjadi aktivitas dan interaksi antara peserta didik yang pandai dengan peserta didik yang kurang pandai di dalam kelas, sehingga dapat saling membantu dalam memecahkan masalah serta dalam menguasai materi pelajaran sehingga akan menunjang hasil belajar yang memuaskan. Hasil penelitian Rediarta dkk (2014:10) pada 
siswa SD Gugus 13 Kecamatan Bulelelng menyebutkan bahwa, "terdapat perbedaan yang signifikan dari hasil belajar IPA antara kelompok siswa yang belajar menggunakan model pembelajaran TSTS dengan kelompok siswa yang belajar menggunakan model pembelajaran konvensional". Kondisi ini perlu ditindaklanjuti dengan melakukan penelitian pada tingkat SMP.

Selain model pembelajaran, faktor internal dari dalam diri siswa berupa kemampuan awal juga merupakan faktor penting yang mempengaruhi hasil belajar IPA peserta didik. Riswanto dan Dasmo (2015:101) mengatakan bahwa, "Pada umumnya peserta didik belajar IPA di kelas tanpa melakukan persiapan sebelumnya, sehingga kemampuan awal peserta didik terbatas. Kondisi ini mengakibatkan informasi yang diberikan guru tidak dengan cepat diterima, sehingga guru perlu mengulang informasi tersebut. Oleh sebab itu, seorang guru diharapkan mampu mengendalikan kemampuan awal peserta didiknya". Kemampuan awal merupakan kemampuan yang telah dimiliki oleh peserta didik sebelum mengikuti pembelajaran. Peserta didik yang memiliki kemampuan awal yang setara bisa menjadi cemerlang atau terpuruk pada satu mata pelajaran, bergantung pada kecintaan atau kebenciannya pada pelajaran itu (Barbara, 2007: 123). Berdasarkan pendapat di atas, dapat dipahami bahwa kemampuan awal adalah sekumpulan pengetahuan dan keterampilan yang dimiliki oleh setiap individu yang diperoleh sepanjang pengalaman hidup. Kemampuan awal ini menjadi penting kedudukannya dalam pembelajaran terutama bagi guru sebagai pijakan untuk menentukan posri pelajaran yang akan diberikan kepada peserta didiknya. Artinya, porsi pelajaran yang diberikan harus disesuaikan dengan kemampuan yang dimiliki peserta didik. Percuma memberikan materi jika pengetahuan peserta didiknya belum sampai kepada apa yang sedang dipelajari. Selain itu, kemampuan awal juga dapat digunakan guru untuk mengambil langkah-langkah dalam proses pembelajaran terkait dengan metode pembelajaran yang akan dilakukan. Dengan demikian jelas kiranya bahwa kemampuan awal dan model pembelajaran merupakan faktor yang dapat mempengaruhi hasil belajar peserta didik.

\section{METODE}

Penelitian ini dilakukan di SMP Negeri 242 Jakarta dengan subyek peserta didik kelas VIII. Sampel dalam penelitian ini berjumlah 60 peserta didik yang terbagi atas 30 peserta didik sebagai kelompok eksperimen dan 30 peserta didik sebagai kelompok kontrol. Sementara itu, penelitian ini merupakan penelitian eksperimen dengan menggunakan pendekatan ANAKOVA untuk menganalisis data. Menurut Supardi (2011:390) penelitian dengan pendekatan ANAKOVA adalah sebuah penelitian ekperimen yang membandingkan antara hasil post-test pada kelompok eksperimen dengan kelompok kontrol, setelah mengendalikan pengaruh pre-test (kemampuan awal). Desain penelitian eksperimen dari model penelitian ini dapat digambarkan sebagai berikut.

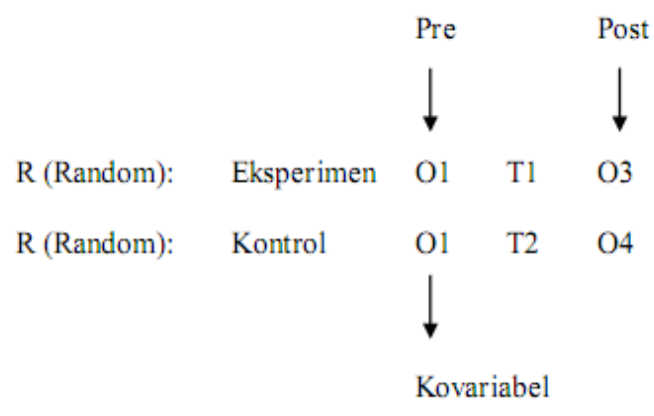


Keterangan:

$\mathrm{O}_{1}$ dan $\mathrm{O}_{2}$ adalah observasi variabel kovariant (pretest)

$\mathrm{O}_{3}$ dan $\mathrm{O}_{4}$ adalah observasi variabel tergantung/kriteria (posttest)

$\mathrm{T}_{1}$ dan $\mathrm{T}_{2}$ adalah kegiatan perlakuan/ treatment pada kelompok eksperimen dan kontrol.

\section{HASIL DAN PEMBAHASAN \\ Hasil}

Jumlah soal yang digunakan dalam penelitian ini berjumlah 17 soal berbentuk pilihan ganda dengan opsi 4 pilihan jawaban yang telah diuji validitas, reliablitas, tingkat kesukaran dan daya beda soalnya. Berdasarkan hasil penelitian, diperoleh hasil bahwa rata-rata skor untuk kemampuan awal kelompok eksperimen (metode two stay two stray) sebesar 13,30. Nilai ini setara dengan 78,24 dalam skala 100. Kondisi ini menunjukkan bahwa kemampuan awal kelompok eksperimen tergolong baik dengan nilai di atas KKM $(70,00)$. Nilai median dan modus pada kelompok ini masing-masing sebesar 13,30 (setara dengan 78,24) dan 13,00 (setara dengan 76,47) dengan standar deviasi sebesar 1,89. Sementara itu, rata-rata untuk skor kemampuan awal kelompok kontrol sebesar 13,00. Nilai ini setara dengan 76,47 dalam skala 100 . Kondisi ini menunjukkan bahwa kemampuan awal kelompok kontrol juga tergolong baik dengan nilai di atas KKM. Sementara itu, nilai median dan modus pada kelompok ini masing-masing sebesar 13,17 (setara dengan 77,47) dan 13,30 (setara dengan 78,24) dengan standar deviasi sebesar 2,14 .

Pada kelompok hasil belajar IPA (post test) jumlah soal yang digunakan berjumlah 34 dengan 4 opsi jawaban. Pada kelompok eksperimen yakni peserta didik yang diajar dengan menggunakan metode two stay two stray diperoleh nilai rata-rata sebesar 27,13. Nilai ini setara dengan 79,79 dalam skala 100 . Kondisi ini menunjukkan bahwa hasil belajar IPA kelompok eksperimen tergolong baik dengan nilai di atas KKM. Nilai median dan modus pada kelompok ini masing-masing sebesar 26,21 (setara dengan 77,09) dan 24,14 (setara dengan 71,00) dengan standar deviasi sebesar 3,38. Sementara itu, nilai ratarata untuk skor hasil belajar IPA kelompok kontrol sebesar 23,50. Nilai ini setara dengan 69,12 dalam skala 100. Kondisi ini menunjukkan bahwa hasil belajar IPA kelompok kontrol tergolong kurang baik karena berada di bawah nilai KKM. Nilai median dan modus pada kelompok ini masing-masing sebesar 22,50 (setara dengan 66,18) dan 20,86 (setara dengan 61,35) dengan standar deviasi sebesar 3,97. Secara deskriptif, data penelitian ini dapat dinyatakan dalam tabel 2 .

Tabel 2. Analisis Deskriptif

\begin{tabular}{|c|c|c|c|c|}
\hline \multirow[t]{2}{*}{ Statistik Deskriptif } & \multicolumn{2}{|c|}{$\begin{array}{c}\text { Two Stay Two } \\
\text { Stray }\end{array}$} & \multicolumn{2}{|c|}{ Konvensional } \\
\hline & Pre test & Post test & $\begin{array}{l}\text { Pre } \\
\text { test }\end{array}$ & Post test \\
\hline Maksimum & 17 & 34 & 16 & 33 \\
\hline Minimum & 9 & 23 & 6 & 17 \\
\hline Rata-rata & 13,30 & 27,13 & 13,00 & 23,50 \\
\hline Median & 13,30 & 26,21 & 13,17 & 22,50 \\
\hline Modus & 13,00 & 24,14 & 13,30 & 20,86 \\
\hline Simpangan baku & 1,89 & 3,38 & 2,14 & 3,97 \\
\hline
\end{tabular}

Sumber: Data primer yang diolah

Berdasarkan hasil pengujian persyaratan analisis data diperoleh hasil bahwa data berdistribusi normal dan homogen. Persyaratan analisis data ini dilakukan untuk 
menentukan hipotesis penelitian yang akan digunakan. Uji normalitas dilakukan menggunakan uji Liliefors dengan kriteria pengujian membandingkan nilai $\mathrm{L}_{\text {hitung }}$ dan $\mathrm{L}_{\text {tabel. }}$. Data dikatakan normal jika $\mathrm{L}_{\text {hitung }}<\mathrm{L}_{\text {tabel. }}$. Berdasarkan hasil pengolahan, semua data berdistribusi normal dimana keempat data memiliki $\mathrm{L}_{\text {hitung }}<\mathrm{L}_{\text {tabel }}$. Hasil pengujian normalitas dapat dilihat dalam tabel 3 .

Tabel 3. Uji Normalitas

\begin{tabular}{cccc}
\hline Kelompok & $\mathrm{L}_{\text {hitung }}$ & $\mathrm{L}_{\text {tabel }}$ & Kesimpulan \\
\hline $\mathrm{X}_{1}$ & 0,105 & 0,161 & normal \\
$\mathrm{X}_{2}$ & 0,110 & 0,161 & normal \\
$\mathrm{Y}_{1}$ & 0,150 & 0,161 & normal \\
$\mathrm{Y}_{2}$ & 0,150 & 0,161 & normal \\
\hline
\end{tabular}

Sumber: Data primer yang diolah

Sementara itu, pengujian homogenitas dilakukan dengan menggunakan uji F. Data dikatakan homogen jika nilai $\mathrm{F}_{\text {hitung }}<\mathrm{F}_{\text {tabel }}$. Berdasarkan hasil pengujian diperoleh kesimpulan bahwa kedua kelompok data bersifat homogen dimana nilai $F_{\text {hitung }}<\mathrm{F}_{\text {tabel }}$. Hasil pengujian homogenitas dapat dilihat dalam tabel 4.

Tabel 4. Uji Homogenitas

\begin{tabular}{cccc}
\hline Kelompok & $\mathrm{F}_{\text {hitung }}$ & $\mathrm{F}_{\text {tabel }}$ & $\begin{array}{c}\text { Kesimpula } \\
\mathrm{n}\end{array}$ \\
\hline $\mathrm{X}_{1}$ dan $\mathrm{X}_{2}$ & 1,166 & 1,861 & homogen \\
$\mathrm{Y}_{1}$ dan $\mathrm{Y}_{2}$ & 1,194 & 1,861 & homogen \\
\hline
\end{tabular}

Sumber: Data primer yang diolah

Setelah semua asumsi persyaratan analisis terpenuhi, pengujian dilanjutkan dengan dengan pengujian hipotesis, yakni dengan teknik ANAKOVA. Dari pengujian hipotesis main effect diperoleh nilai $\mathrm{F}_{\mathrm{h}}$ antar kolom sebesar 15,05. Nilai ini lebih besar dibandingkan dengan nilai $F_{t}$ yang bernilai 4,01. Dengan membandingkan nilai antara $F_{h}$ dan $F_{t}$ tersebut, maka uji hipotesis ini memenuhi kriteria $\mathrm{H}_{1}$. Artinya dengan mengontrol/mengendalikan pengaruh kemampuan awal $(\mathrm{X})$, terdapat perbedaan hasil belajar IPA (Y) peserta didik yang belajar dengan metode pembelajaran two stay two stray dan metode pembelajaran konvensional. Jika dilihat berdasarkan perbedaan nilai rata-rata, kelompok siswa yang diberikan metode pembelajaran two stay two stray memiliki nilai rata-rata 27,133 (setara dengan 79,80). Sementara yang diajar dengan metode konvensional sebesar 23,50 (setara dengan 69,12). Sementara itu, dari pengujian simple effect diperoleh $\mathrm{t}_{\text {hitung }}$ sebesar 3,89 dan $\mathrm{t}_{\text {tabel }}$ 1,672. Dengan demikian disimpulkan bahwa dengan mengontrol/mengendalikan pengaruh kemampuan awal (X), secara signifikan hasil belajar IPA (Y) peserta didik yang belajar menggunakan metode pembelajaran TSTS lebih besar dari pada yang menggunakan metode pembelajaran konvensional.

\section{Pembahasan}

Hasil belajar IPA adalah perubahan tingkah laku berupa kemampuan-kemampuan yang dimiliki peserta didik setelah menerima pengalaman belajar IPA, dimana pengalaman tersebut merupakan macam-macam kemampuan, keterampilan dan sikap dalam bidang IPA. Tujuan utama dari belajar IPA ialah peningkatan kemampuan dan 
keterampilan. Peningkatan hasil belajar akan dapat dicapai jika peserta didik diberi kesempatan untuk mengikuti proses belajar dan mengalami secara utuh dari setiap kegiatan yang ada pancapaian hasil belajar berkaitan erat dengan proses belajar yang dialami peserta didik. Semakin baik proses belajar yang diikuti seseorang akan semakin baik pula hasil belajarnya. Sebaliknya jika situasi belajar berlangsung dalam keadaan yang kurang kondusif maka pada akhirnya berakibat buruk terhadap rata-rata hasil belajar peserta didik.

Penelitian ini membuktikan bahwa dengan mengontrol/mengendalikan pengaruh kemampuan awal, terdapat pengaruh yang signifikan model pembelajaran TSTS terhadap hasil belajar IPA peserta didik. Atas dasar hal tersebut, model pembelajaran sebagai landasan praktik pembelajaran yang dirancang berdasarkan analisis terhadap implementasi kurikulum dan implementasinya pada tingkat operasional dikelas memiliki kedudukan yang penting terhadap keberhasilan belajar peserta didik, salah satunya adalah dengan merapkan model TSTS dalam pembelajaran IPA. Isjoni (2011:113) mengatakan bahwa, "metode Two Stay Two Stray ini memberi kesempatan kepada peserta didik untuk membagikan hasil informasi dengan kelompok lain". Model pembelajaran TSTS merupakan model pembelajaran berkelompok dimana di dalam kelompok tersebut peserta didik berperan sebagai penamu yang bertugas mencari informasi berupa materi ke kelompok lain, dan peserta didik lainnya sebagai tuan rumah yang bertugas memberikan informasi berupa materi kepada sipenamu. Dengan model seperti ini, peserta didik menjadi aktif, berani mengungkapkan pendapat dan mampu mengembangkan kemampuan berpikirnya.

Berdasarkan hasil pengamatan selama penelitian berlangsung, peserta didik yang diajar dengan menggunakan model TSTS lebih berani untuk bertanya dan mengemukakan pendapat dibandingkan dengan peserta didik yang belajar secara konvensional. Selain itu, peserta didik lebih aktif untuk mencari informasi terkait materi pembelajaran dan berusaha untuk menjelaskan kembali materi tersebut kepada kelompok lainnya. (Rediarta dkk, 2014:10) menyebutkan bahwa, "Dalam pembelajaran TSTS, siswa diberikan pembagian tugas yang jelas, dituntut untuk mampu bekerjasama dengan baik di dalam kelompok, dan dapat menimbulkan minat siswa untuk belajar. Dengan demikian siswa memiliki rasa kebersamaan, rasa tanggung jawab yang mengakibatkan siswa tidak akan melalaikan dan mengabaikan tugasnya dalam berkelompok sehingga dapat memberikan hasil yang optimal terhadap hasil belajar siswa. Sedangkan pada pembelajaran konvensional, siswa tidak diberikan pembagian tugas yang jelas dalam berkelompok, guru merupakan pusat pembelajaran, dan kurangnya kerjasama dalam kegiatan pembelajaran akan membuat siswa cenderung hanya sebagai pelaku belajar yang pasif. Hal tersebut berimplikasi langsung pada proses pembelajaran di kelas, yaitu pada situasi kelas akan menjadi pasif karena interaksi hanya berlangsung satu arah. Dengan keadaan seperti itu, siswa tidak akan mampu memperoleh hasil belajar yang optimal."

Selain model pembelajaran yang tepat, dalam proses pembelajaran guru juga harus memperhatikan kemampuan awal peserta didik. Kemampuan awal dapat dijadikan landasan guru untuk menentukan model yang tepat dalam pembelajaran. Kemampuan awal merupakan landasan seberapa dalam materi yang akan diberikan guru dalam proses pembelajaran selain penentuan langkah-langkah metode atau model pembelajaran yang akan dipakai. Berdasarkan hal tersebut maka dapat dipahami bahwa model dan kemampuan awal peserta didik merupakan dua hal yang harus diperhitungkan guru dalam mengajar. 


\section{PENUTUP}

\section{Simpulan}

Berdasarkan hasil pengujian hipotesis penelitian dan analisis pengolahan data, maka dapat disimpulkan sebagai berikut. Pertama, dengan mengontrol/ mengendalikan pengaruh kemampuan awal, terdapat perbedaan hasil belajar IPA yang signifikan antara peserta didik yang belajar menggunakan metode pembelajaran two stay two stray dengan yang menggunakan metode pembelajaran konvensional. Hal ini dibuktikan oleh nilai $F_{h}$ antar kolom sebesar 15,05. Nilai ini lebih besar dibandingkan dengan nilai $F_{t}$ yang bernilai 4,01. Kedua, dengan mengontrol/ mengendalikan pengaruh kemampuan awal, hasil belajar IPA peserta didik yang belajar menggunakan metode pembelajaran two stay two stray lebih besar daripada yang belajar menggunakan metode pembelajaran konvensional. Hal ini dibuktikan oleh nilai $t_{\text {hitung }}$ sebesar 3,89 yang lebih besar dari $t_{\text {tabel }}$ sebesar 1,672 .

\section{Saran}

Saran yang perlu disampaikan terkait hasil penelitian diatas adalah: Guru diharapkan bisa menjadikan metode two stay two stray sebagai salah satu alternatif metode pembelajaran yang bisa digunakan dalam proses pembelajaran IPA. Dalam pelaksanaannya, sebelum pembelajaran guru terlebih dahulu mempersiapkan dan membentuk kelompok-kelompok belajar yang heterogen ditimjau dari segi jenis kelamin, dan kemampuan akademiknya.

\section{DAFTAR PUSTAKA}

Barbara, G. K. 2007. Brain-Based Teaching. Penerjemah: Lala Herawatidarma. Bandung: Kaifa.

Isjoni dan Arif Ismail. 2011. Model-Model Pembelajaran Mutakhir. Yogyakarta: Pustaka Belajar.

Leonard, L., Hasbullah, H., \& Nurani, S. 2016. Learning design of research methodology: A need analysis. Prosiding. Educational Technology World Conference (ETWC), Bali, 31 Juli-3 Agustus 2016.

Lie, A. 2006. Mempraktekkan Cooperative Learning di Ruang-Ruang Kelas. Jakarta: PT Gramedia.

Maonde, F., dkk. 2015. The discrepancy of students' mathematic achievement through cooperative learning model, and the ability in mastering languages and science. International Journal of Education and Research, 3 (1): 141-158.

Riswanto, H. \& Dasmo. 2015. Upaya meningkatkan hasil belajar ilmu pengetahuan alam (ipa) dengan metode pembelajaran mind map. Jurnal Formatif, 5(2):100106.

Rediarta, I Wayan dkk. 2014. Pengaruh model kooperatif two stay two stray terhadap hasil belajar IPA. Jurnal Mimbar PGSD Universitas Pendidikan Ganesha Jurusan PGSD, 2 (1): 1-11.

Saraswati, In Diyah dkk. 2012. Penerapan pembelajaran two stay-two stray terhadap kemampuan pemahaman konsep dan minat. Unnes Journal of Mathematics Education, 1 (1): 32-37.

Supardi. 2011. Aplikasi Statistika dalam Penelitian. Jakarta: Ufuk Press.

Suprijono, A. 2006. Cooperative Learning Teori dan Aplikasi PAIKEM. Yogyakarta: Pustaka Pelajar. 